\title{
FIRST OBSERVATION OF POLYGYNY IN FIRE ANTS, SOLENOPSIS SPP., IN SOUTH AMERICA*
}

\author{
By Donald P. Jouvenaz, Daniel P. Wojcik, \\ and Robert K. VANDER Meer \\ USDA-ARS, Insects Affecting Man and Animals \\ Research Laboratory, 1600 SW 23rd Drive \\ Gainesville, FL 32604
}

Polygyny, the coexistence of two or more egg-laying queens in a single colony of a social insect, occurs in several subfamilies of ants (Wilson 1971). The species of Solenopsis, however, were considered to be monogynous until Banks et al. (1973), and Glancey et al. (1973) observed polygyny in Solenopsis geminata (F.) and Solenopsis invicta Buren, respectively. Subsequently, Summerlin (1976) found a single polygynous colony of Solenopsis xyloni McCook. The existence of a spectrum from monogyny to extreme polygyny in the North American S. invicta population was substantiated by Fletcher et al. (1980). Populations of polygynous S. invicta are now known from Florida, Georgia, Mississippi, Louisiana, Texas (Lofgren and Williams 1984), Alabama, Arkansas, and Oklahoma (Banks and Wojcik unpublished). These populations are spreading, and in some cases are proving to be more difficult to control with pesticides than monogynous populations (Glancey et al. 1987). They are also characterized by increased densities of both ants and mounds (Lofgren and Williams 1984). Thus, polygyny in fire ants is currently a subject of interest and concern.

We have not encountered polygynous colonies in our extensive surveys for biological control agents for fire ants in the states of Mato Grosso and Mato Grosso do Sul, Brazil, the presumed homeland of S. invicta (Wojcik 1986). Recently, however, we extended our surveys to Argentina, where we collected colonies of polygynous Solenopsis richteri Forel and Solenopsis quinquecuspis Forel.

We were alerted to the possibility that we had encountered polygynous fire ants by the enormous biomass of brood in a colony of $S$. richteri, which has been separated from the soil by flotation (Banks et al. 1981). This colony yielded 16 non-physogastric, dealate

${ }^{*}$ Manuscript received by the editor June 14, 1989. 
females, all of whom were highly attractive to workers. Ten of these were dissected in physiologic saline; their spermathecae contained motile sperm (phase-contrast microscopy) and their ovaries contained developing and mature oocytes. The remaining six were held for 30 days in separate petri dishes, each of which contained ca 25 worker ants and a cylinder of damp paper toweling which served as a nest chamber. They were fed insects, honey, and peanut butter. The laboratory was heated only with a small space heater, and temperatures ranged from ca $20^{\circ}-24^{\circ} \mathrm{C}$ ( $28^{\circ}$ is optimal). Nevertheless, all six queens produced worker brood.

A total of 16 polygynous colonies from eight sites in Buenos Aires Province were among 295 colonies of fire ants from 33 sites in Buenos Aires and Santa Fe provinces which we separated from the soil and examined for pathogens and symbiotic arthropods. Twelve of these were identified as $S$. richteri chromatotype I (Vander Meer, unpublished), and the remaining four as Solenopsis quinquecuspis Forel. These identifications were based on the species-specific cuticular hydrocarbon and venom alkaloid gas chromatographic profiles, which had been previously correlated with morphological species identifications (Vander Meer and Trager, unpublished). The venom alkaloids and cuticular hydrocarbons were obtained for chemotaxonomic analysis by placing worker ants in new vials containing HPLC grade $n$-hexane and capped with aluminum foil-lined caps. After standing at room temperature overnight, the hexane was transferred by Pasteur pipette to new, loosely capped vials, allowed to evaporate, and the caps tightened. The vials were hand-carried to our Gainesville, Florida laboratory where they were reconstituted with HPLC grade $n$-hexane and analyzed by gas chromatography (Vander Meer et al. 1985; Ross et al. 1987). Worker ants from every colony examined were preserved in $70 \%$ isopropanol as taxonomic voucher specimens.

The 16 polygynous colonies yielded a total of 116 inseminated queens. From one to three uninseminated, dealate females were also found in five of these colonies (Table I). The gasters of 59 (50.9\%) of the inseminated queens were moderately to greatly distended (the sclerites were separated). Their ovaries contained numerous mature and developing oocytes. Although these queens were not weighed, we considered them to be physogastric. 
Table 1. Polygynous colonies of Solenopsis richteri ${ }^{1}$ and Solenopsis quinquecuspis and collection sites in the province of Buenos Aires, Argentina.

\begin{tabular}{|c|c|c|c|}
\hline $\begin{array}{l}\text { Collection } \\
\text { Sites }^{2}\end{array}$ & Species & 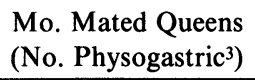 & $\begin{array}{l}\text { No. Unmated } \\
\text { Dealates }\end{array}$ \\
\hline Escobar & S. quinquecuspis & $2(2)$ & 3 \\
\hline Campana & S. richteri & $16(0)$ & 0 \\
\hline Mercedes & S. richteri & 2 (2) & 0 \\
\hline \multirow[t]{3}{*}{ Suipacha } & S. richteri & 3 (3) & 0 \\
\hline & S. richteri & 9 (9) & 0 \\
\hline & S. quinquecuspis & $3(0)$ & 0 \\
\hline \multirow[t]{2}{*}{ Corbet } & S. richteri & $11 \quad(0)$ & 0 \\
\hline & S. richteri & $4 \quad(4)$ & 3 \\
\hline \multirow[t]{4}{*}{ Del Carril } & S. richteri & 21 (2) & 2 \\
\hline & S. richteri & 2 (2) & 0 \\
\hline & S. richteri & $4 \quad(0)$ & 0 \\
\hline & S. richteri & $3(0)$ & 1 \\
\hline \multirow[t]{2}{*}{ Pergamino } & S. quinquecuspis & 2 (2) & 0 \\
\hline & S. quinquecuspis & 2 (1) & 1 \\
\hline \multirow[t]{2}{*}{ Villa Espril } & S. richteri & $4 \quad(4)$ & 0 \\
\hline & S. richteri & $28 \quad(28)$ & 0 \\
\hline Totals & & $116 \quad(59)$ & 10 \\
\hline $\begin{array}{l}\text { Mean SD } \\
\text { Queens/colony }\end{array}$ & & 7.255 .77 & \\
\hline
\end{tabular}

'All S. richteri belong to venom alkaloid/hyrdocarbon chromatotype I.

${ }^{2} \mathrm{~A}$ total of 10 colonies were collected at each site.

${ }^{3}$ Physogastric in appearance (not weighed).

Two colonies of $S$. richteri each contained one inseminated and two uninseminated, yet apparently functional queens. All three queens from one of these colonies were highly physogastric in appearance, and their ovaries were engorged with developing and mature oocytes; however, the spermatheca of only one contained sperm. The appearance of the three queens from the other colony was moderately physogastric, and their ovaries also contained numerous oocytes. One colony of $S$. quinquecuspis yielded 10 uninseminated queens, all of whom were highly physogastric in appearance; their ovaries were engorged with developing and mature oocytes. No inseminated queens were found in this colony, but failure to collect the queen by flotation is not unusual. Fletcher et al. (1980) found a functional, uninseminated queen in eight polygynous colonies of $S$. invicta in the United States. They suggested that such females may occur in most polygynous colonies, and may contribute 
to the male population. Tschinkel and Howard (1978) reported that over one-fourth of experimentally orphaned (monogynous queen removed) colonies of $S$. invicta replaced the lost queen with parthenogenetic (uninseminated, worker-producing) queens. Most of their orphaned colonies replaced lost queens with uninseminated, maleproducing queens.

Fletcher et al. (1980) emphasized that they found no highly physogastric queens in 15 polygynous colonies of $S$. invicta Mississippi, whereas the queens they collected from monogynous colonies at the same time were highly physogastric. In contrast, the polygynous colonies of both $S$. richteri and $S$. quinquecuspis which we observed in Argentina contained queens which we considered to be highly physogastric.

The polygynous colonies from Argentina were collected at the same sites as monogynous colonies; no pattern of distribution of the two forms was evident.

In our search for natural enemies of fire ants, we have examined over 1,500 colonies, and have opened hundreds of additional mounds (primarily of $S$. invicta) in the states of Mato Grosso and Mato Grosso do Sul, Brazil. Although our search has been for pathogens and arthropod symbionts, we are confident that we have not overlooked polygynous fire ants there. The apparent absence of polygynyny in $S$. invicta in an area that has been regarded as its native range, and its now widespread occurrence in North America, is indeed an enigma. Perhaps all Solenopsis spp. are potentially polygynous, but the trait is more readily expressed in temperate than in tropical climes.

\section{ReFERENCes Cited}

Banks, W. A., J. K. Plumley \& D. M. Hicks. 1973. Polygyny in a colony of the fire ant, Solenopsis geminata (F.). Ann. Entomol. Soc. Amer. 66: 234-235.

Banks, W. A., C. S. Lofgren, D. P. Jouvenaz, C. E. Stringer, P. M. Bishop, D. F. Williams, D. P. WoJcik, \& B. M. Glancey. 1981. Techniques for collecting, rearing, and handling fire ants. USDA, SEA AATS-S-21, $9 \mathrm{pp}$.

Fletcher, D. J. C., M. S. Blum, T. V. Whitt, \& N. Temple. 1980. Monogyny and polygyny in the fire ant, Solenopsis invicta. Ann. Entomol. Soc. Amer. 73: 658-661.

Glancey, B. M., C. H. Craig, C. E. Stringer, \& P. M. Bishop. $1973 . \quad$ Multiple fertile queens in colonies of the imported fire ant, Solenopsis invicta. J. Ga. Entomol. Soc. 8: 237-238. 
Glancey, B. M., J. C. E. Nickerson, D. Wojcik, J. Trager, W. A. Banks, \& C. T. ADAms. 1987. The increasing incidence of the polygynous form of the red imported fire ant, Solenopsis invicta (Hymenoptera: Formicidae) in Florida. Fla. Entomol. 70: 400-402.

Lofgren, C. S. \& D. F. Williams. 1984. Polygynous colonies of the red imported fire ant, Solenopsis invicta (Hymenoptera: Formicidae) in Florida. Fla. Entomol. 67: 484-486.

Ross, K. G., R. K. Vander Meer, D. J. C. Fletcher, \& E. L. Vargo. $1987 . \quad$ Biochemical, phenotypic, and genetic studies of two introduced fire ants and their hybrid. Evolution 41: 280-293.

Summerlin, J. W. 1976. Polygyny in a colony of the southern fire ant. Ann. Entomol. Soc. Amer. 69: 54.

TSCHINKel, W. R. AND D. F. Howard. 1978. Queen replacement in orphaned colonies of the fire ant, Solenopsis invicta. Behav. Ecol. Sociobiol. 3: 297-320.

Vander Meer, R. K., C. S. Lofgren, \& F. M. Alvarez. 1985. Biochemical evidence for hybridization in fire ants. Fla. Entomol. 68: 501-506.

Wilson, E. O. 1971. The insect societies. Belknap Press. Cambridge, Mass. 548 pp.

WoJcIK, D. P. 1986. Observations on the biology and ecology of fire ants in Brazil. pp. 88-103. In C. S. Lofgren \& R. K. Vander Meer (eds.), Fire ants and leaf-cutting ants, biology and management. Westview Press, Boulder, CO. 435 pp. 

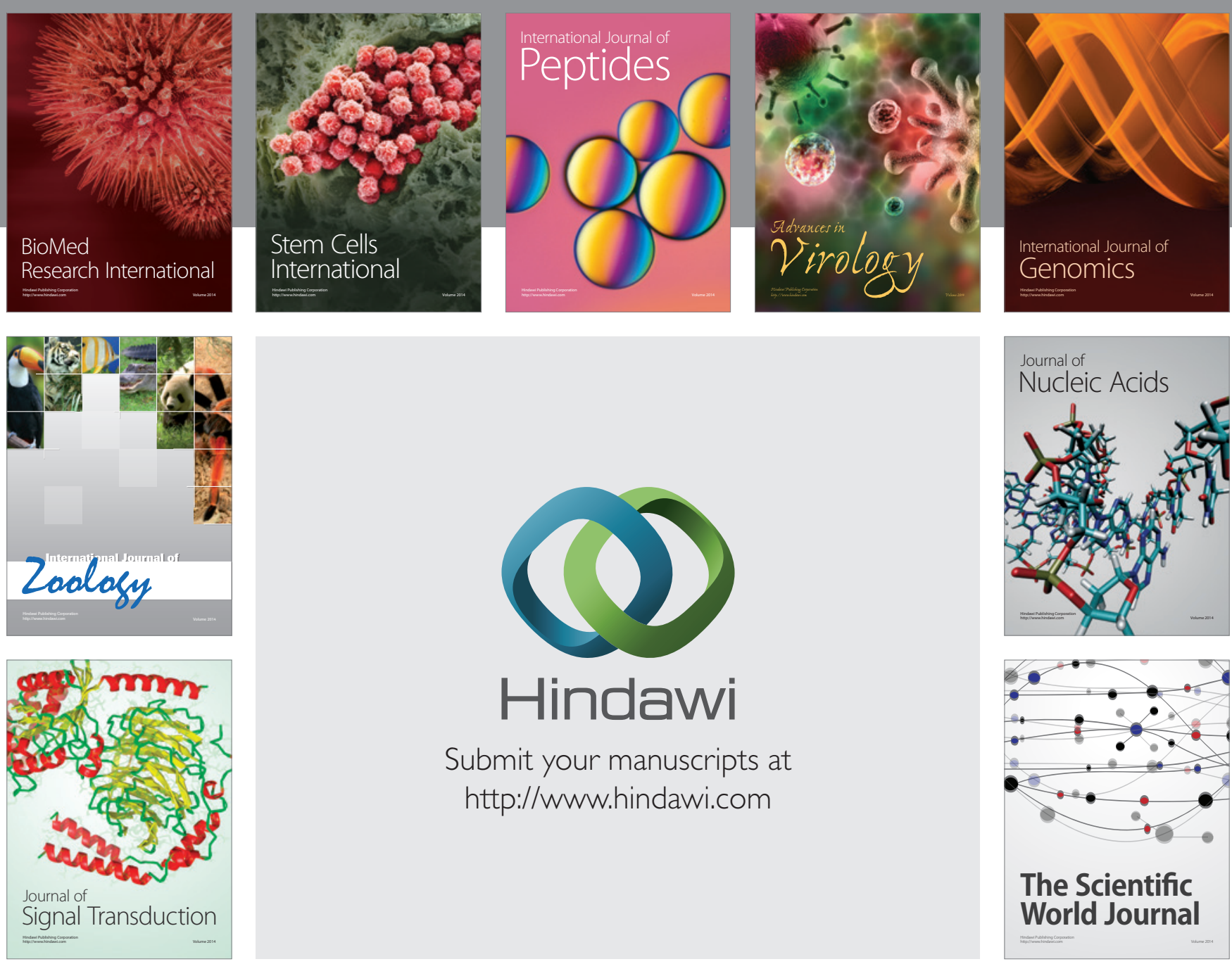

Submit your manuscripts at

http://www.hindawi.com
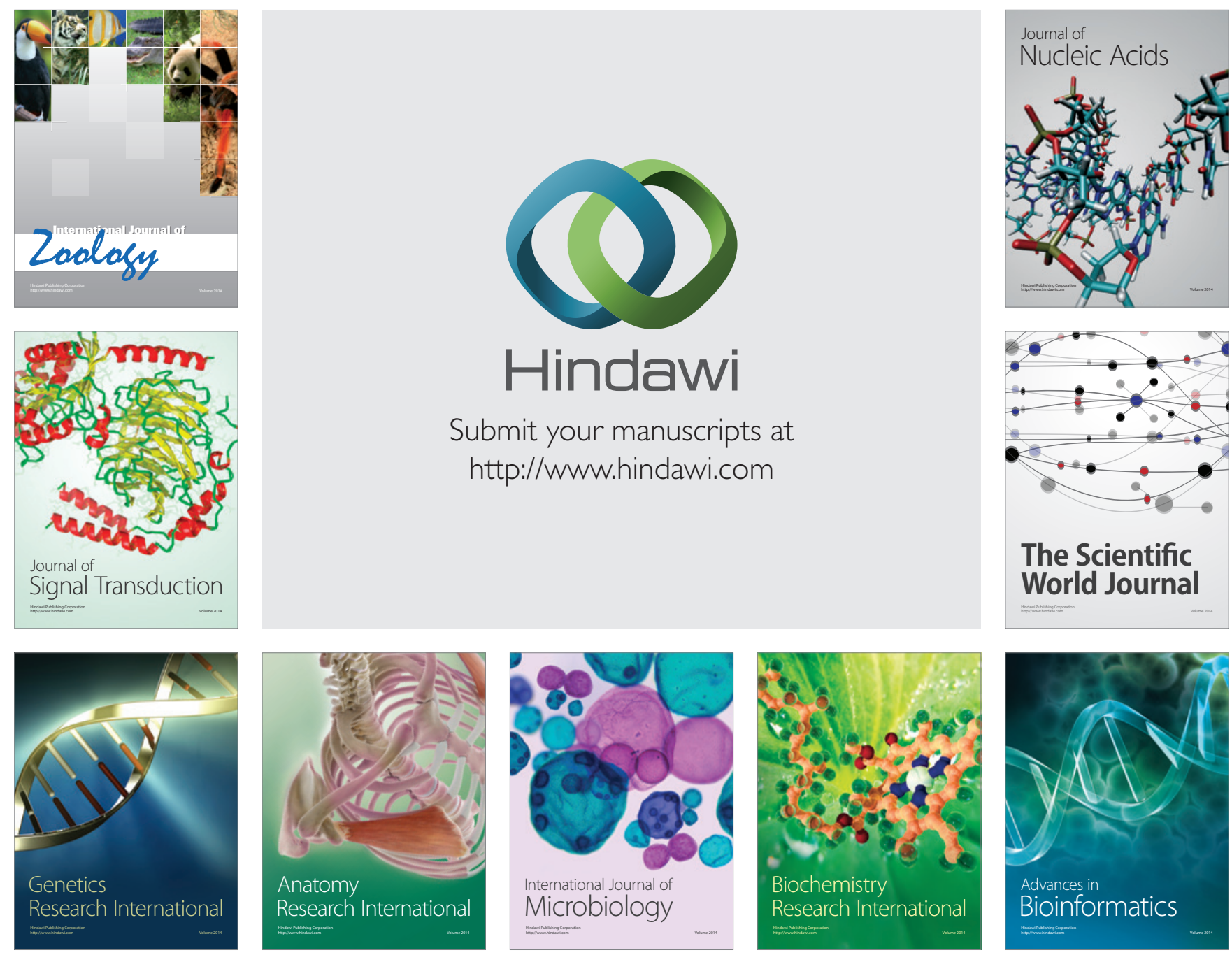

The Scientific World Journal
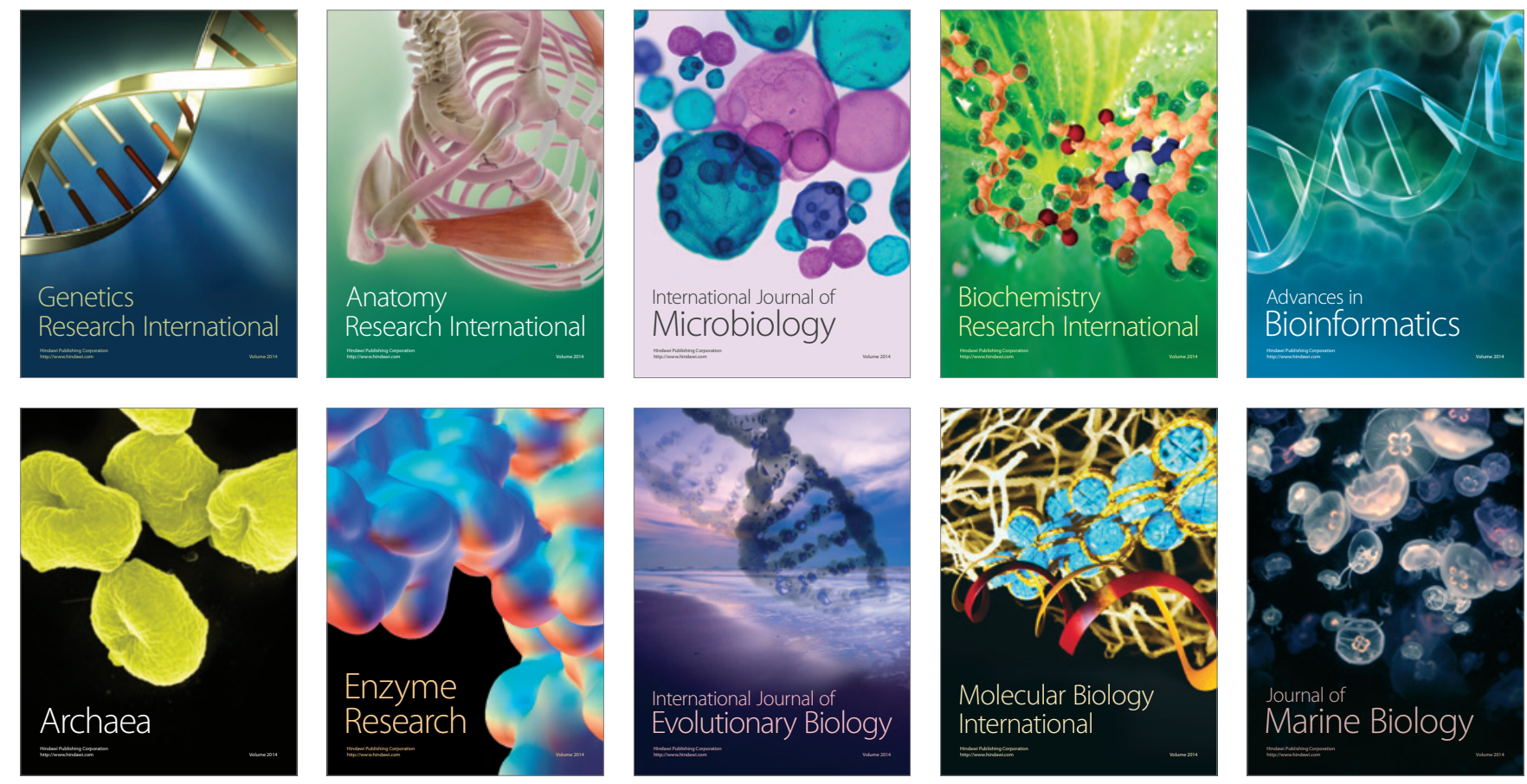